Nobuko Fukuhara DDS, ${ }^{\star}$

Toshizo Ishikawa PhD, Hiroyuki Kinoshita MD, Lize Xiong MD, Osamu Nakanishi DDs*

\section{Central noradrenergic mediation of nitrous oxide-induced analgesia in rats}

Purpose: Although several studies have demonstrated that both supra opiate receptors and spinal $\alpha_{2}$ adrenoceptors play a mediating role in nitrous oxide $\left(\mathrm{N}_{2} \mathrm{O}\right)$ analgesia, controversy still exists. The present study was undertaken to evaluate further the involvement of noradrenergic (NA) neuronal activity in $\mathrm{N}_{2} \mathrm{O}$ analgesia by investigating tail-flick latency and supra-and spinal NA levels in rats.

Methods: In an analgesia study, effect of $\mathrm{N}_{2} \mathrm{O} 75 \%$ and its modification were evaluated using the tail-flick test in male Wistar rats. Results were expressed as \% maximum possible effect (MPE). Modification of $\mathrm{N}_{2} \mathrm{O}$ analgesia was examined in rats pretreated with either the $\alpha_{2}$ receptor agonist, clonidine $\left(C L O: 150 \mu g \cdot \mathrm{kg}^{-1}\right.$, ip), $\alpha_{2}$ receptor antagonist, idazoxone(IDZ: $100 \mu \mathrm{g}^{\circ \mathrm{g}^{-1}}$, iv) by lesioning the locus coeruleus (LC) seven days before exposure to $\mathrm{N}_{2} \mathrm{O}$, or naloxone $\left(5 \mathrm{mg} \cdot \mathrm{kg}^{-1}, \mathrm{iv}\right)$. Also, in a NAergic neuronal transmission study, the changes in NA content at $\mathrm{LC}$ and spinal cord were determined using HPLC-ECD.

Results: Nitrous oxide produced analgesia, \% MPE increased to a maximum of $78 \%$ at $30 \mathrm{~min}$, thereafter declining to $38 \%$ at $120 \mathrm{~min}$. Clonidine potentiated the analgesic effect of $\mathrm{N}_{2} \mathrm{O}$ at $120 \mathrm{~min}(80 \%)$. The analgesic effect of $\mathrm{N}_{2} \mathrm{O}$ was attenuated by IDZ or by $\mathrm{LC}$ lesioning. However, naloxone, in a dose sufficient to block morphineinduced analgesia, had no effect. With $\mathrm{N}_{2} \mathrm{O}$ exposure, NA content was decreased by $52 \%$ in the LC and by $20 \%$ at spinal cord. With morphine, NA content did not differ from the control group.

Conclusion: The data suggest that $\mathrm{N}_{2} \mathrm{O}$-induced analgesia is principally mediated by activation of the descending inhibitory NAergic system and/or increased NA release at spinal cord which may lead to presynaptic inhibition of primary afferent neurotransmitter release and hyperpolarize the dorsal hom neurons by $\alpha_{2}$ receptors.

Objectif : Bien que plusieurs études aient démontré que les suprarécepteurs opiacés et les récepteurs $\alpha_{2}$ adrénergiques rachidiens jouent un rôle de médiation dans l'analgésie au protoxyde d'azote $\left(N_{2} \mathrm{O}\right)$, la controverse persiste. La présente étude a été entreprise pour évaluer plus amplement la participation de l'activité neuronale noradrénergique (NA) dans l'analgésie avec $\mathrm{N}_{2} \mathrm{O}$ en examinant le temps de latence des coups de queue et les niveaux noradrénergiques des suprarécepteurs et des récepteurs rachidiens.

Méthode : Dans une étude sur l'analgésie, l'effet du $\mathrm{N}_{2} \mathrm{O} 75 \%$ et des modifications qu'il produit ont été évalués en utilisant la technique du coup de queue chez des rats mâles Wistar. Les résultats ont été exprimés en termes de pourcentage de l'effet maximal possible (EMP). La modification de l'analgésie au $\mathrm{N}_{2} \mathrm{O}$ a été étudiée chez des rats prétraités avec l'agoniste du récepteur $\alpha_{2}$, la clonidine (CLO : I50 $\mu \mathrm{g} \cdot \mathrm{kg}^{-1}$, ip), l'antagoniste du récepteur $\alpha_{2}$, l'idazoxone (IDZ: $100 \mu \mathrm{g}^{-} \mathrm{kg}^{-1}$, iv) en sectionnant le locus coeruleus (LC) sept jours avant l'exposition au $\mathrm{N}_{2} \mathrm{O}$, ou avec du naloxone $\left(5 \mathrm{mg} \cdot \mathrm{kg}^{-1}, \mathrm{iv}\right)$. Également, dans l'étude de la transmission neuronale noradrénergique, les changements de contenu de noradrénaline dans le LC et dans la moelle épinière ont été déterminés en utilisant la CLHP (chromatographie liquide à haute performance) et le DCE (détecteur à capture d'électrons).

Résultats : Lors de l'analgésie produite par le protoxyde d'azote, le pourcentage de l'EMP a augmenté pour atteindre $78 \%$ à $30 \mathrm{~min}$, pour décliner par la suite à $38 \%$ à $120 \mathrm{~min}$. La clonidine a potentialisé l'effet analgésique du $\mathrm{N}_{2} \mathrm{O}$ à 120 min (80\%). L'effet analgésique du $\mathrm{N}_{2} \mathrm{O}$ a été diminué par l'IDZ ou par la section du LC. Cependant, le naloxone, en dose suffisante pour bloquer l'analgésie induite par la morphine, n'a pas eu d'effet. Avec l'exposition au $\mathrm{N}_{2} \mathrm{O}$, le contenu de noradrénaline a diminué de $52 \%$ dans le $\mathrm{LC}$ et de $20 \%$ à la moelle épinière. Avec la morphine, le contenu de noradrénaline n'a pas été différent de celui du groupe témoin.

Conclusion : Les données suggèrent que l'analgésie induite par le $\mathrm{N}_{2} \mathrm{O}$ bénéficie principalement de la médiation de l'activation du système noradrénergique inhibiteur descendant et/ou de la libération accrue de noradrénaline au niveau de la moelle épinière qui peut mener à une inhibition présynaptique de la libération du neurotransmetteur afférent primaire et à l'hyperpolarisation des neurones de la corne supérieure par les récepteurs $\alpha_{2}$.

From the Department of Anaesthesiology-Resuscitology, Yamaguchi University School of Medicine, 1144 Kogushi, Ube, Yamaguchi 755-8505 Japan and Department of Dental Anaesthesiology, Kyushu Dental College, * 2-6-1 Manazuru, Kokura-kita, Kitakyushu, 803-8580 Japan.

Address correspondence to: Dr. T. Ishikawa, Department of Anaesthesiology-Resuscitology, Yamaguchi University School of Medicine, 1144 Kogushi, Ube, Yamaguchi 755-8505, Japan. Phone: 81-836-22-2291; Fax: 81-836-22-2292; E-mail: medlibn@po.cc.yamaguchi-u.ac.jp Accepted for Publication September 4, 1998 
$\mathrm{N}$

ITROUS oxide $\left(\mathrm{N}_{2} \mathrm{O}\right)$ has a potent antinociceptive action but the mechanism is uncertain. Kitahata $e t$ al. ${ }^{1}$ demonstrated electrophysiologically that $\mathrm{N}_{2} \mathrm{O}$ inhibited the spontaneous firing of wide dynamic range (WDR) neurons of the spinal cord in decerebrate and spinal cats, suggesting that the antinociceptive action of $\mathrm{N}_{2} \mathrm{O}$ may involve inhibition of neuronal transmission at the spinal level.

Further investigations suggested that $\mathrm{N}_{2} \mathrm{O}$ may interact with opioid receptors at both spinal and supraspinal levels. ${ }^{2-5}$ Berkowitz et al. ${ }^{2}$ reported, in rats, that $\mathrm{N}_{2} \mathrm{O}$ had a potent antinociceptive effect to chemical and heat stimuli, and that this effect was antagonized by naloxone. In addition, Zuniga et al. ${ }^{5}$ showed that the analgesic effect of $\mathrm{N}_{2} \mathrm{O}$ was attenuated by lesioning of periaquaductal gray matter (PAG) in rats and that $\mathrm{N}_{2} \mathrm{O}$ increased content of B-endorphin of PAG. ${ }^{4}$ However, the importance of their opioid-related mechanisms is uncertain because of the extremely large amount of naloxone needed to antagonize $\mathrm{N}_{2} \mathrm{O}$ analgesia. ${ }^{2}$

It has recently been demonstrated that noradrenergic (NA) nerve tracts originating from the locus coeruleus (LC) or A7 neurons are innervated by presynaptic terminals of $\mathrm{C}$ fibres and that the WDR of the spinal cord, the descending NAergic inhibitory system, and $\alpha_{2}$ receptors are densely localized in the dorsal horn neurons of the spinal cord, ${ }^{10}$ suggesting that spinal $\alpha_{2}$ receptors may modulate primary afferent input. Intrathecal ( $i t$ ) injection of NA or the $\alpha_{2}$ receptor agonist, clonidine, produced potent analgesic effects assessed by acute, ${ }^{11}$ hyperalgesic ${ }^{12}$ or neuropathic pain states. ${ }^{13}$ These effects were counteracted by the simultaneous delivery of an $\alpha_{2}$ receptor antagonist. ${ }^{14}$ Since $\mathrm{N}_{2} \mathrm{O}$ stimulates the central NAergic system, the analgesic action of $\mathrm{N}_{2} \mathrm{O}$ might be mediated by the effect on this system. Also, Guo et al. ${ }^{15}$ has suggested that both supra-spinal opioid and spinal $\alpha_{2}$ adrenoceptors mediate the antinociceptive response to $\mathrm{N}_{2} \mathrm{O}$ in rats.

Accordingly, the present study was undertaken to evaluate further the effect of $\mathrm{N}_{2} \mathrm{O}$ on NAergic neuronal activity at supra-spinal and spinal levels in relation to NAergic neuronal transmission. In addition, the effects of $\mathrm{N}_{2} \mathrm{O}$ were compared with those of morphine.

\section{Materials and methods}

The experimental protocols were approved by the Ethics Committee for Animal Experimentation at Yamaguchi University School of Medicine and Kyushu Dental College, and carried out according to the Guidances for Animal Experimentation at Yamaguchi University School of Medicine, and The Law (No, 105) and Notification (No, 6) of the Japanese Government.

\section{Animals}

Male Wistar rats, weighing 250 to $350 \mathrm{~g}$, were housed with lights on from 7:00 to 19:00 and allowed free access to food and water.

\section{Protocol for evaluation of analgesia}

Under halothane, 2-3\%, anaesthesia, a PE-50 catheter was inserted into the femoral vein for drug administration. Then, anaesthesia was discontinued and the rats were placed individually in specially designed plastic boxes $(7 \times 7 \times 7 \mathrm{~cm})$ for at least $30 \mathrm{~min}$ for stabilization. Rats were randomly assigned to one of seven groups:

i) Control group ( $\mathrm{n}=8$ ): Rats breathed $\mathrm{N}_{2} 75 \%$ in $\mathrm{O}_{2}$.

ii) No pretreatment $\left(\mathrm{N}_{2} \mathrm{O}\right.$ alone) $(\mathrm{n}=8)$ : Rats received saline, $i v$, five minutes before $\mathrm{N}_{2} \mathrm{O}$ exposure.

iii) Clonidine group ( $\mathrm{n}=8$ ): $150 \mu \mathrm{g} \cdot \mathrm{kg}^{-1}$ clonidine ip was given $30 \mathrm{~min}$ before $\mathrm{N}_{2} \mathrm{O}$ exposure.

iv) Idazoxane group $(\mathrm{n}=8): 100 \mu \mathrm{g} \cdot \mathrm{kg}^{-1}$ idazoxane $i p$ was given at the start of $\mathrm{N}_{2} \mathrm{O}$ exposure.

v) LC lesion group $(n=3)$ : An LC lesion was made by electrical coagulation seven days before $\mathrm{N}_{2} \mathrm{O}$ exposure. The lesion was confirmed by postmortem microscopical examination.

vi) Morphine group ( $\mathrm{n}=5$ ): $5 \mathrm{mg} \cdot \mathrm{kg}^{-1}$ morphine, $i v$ was given five minutes before $\mathrm{N}_{2}$ exposure.

vii) Naloxone group $(\mathrm{n}=10): 5 \mathrm{mg} \cdot \mathrm{kg}^{-1}$ naloxone, $i v$ was given either by simultaneous delivery with morphine five minutes before $\mathrm{N}_{2}$ exposure $(\mathrm{n}=5)$ or at the start of exposure to $\mathrm{N}_{2} \mathrm{O}(\mathrm{n}=5)$.

Throughout the experiments, rectal temperature was kept at $37.2 \pm 0.2^{\circ} \mathrm{C}$ by a heating lamp. After the start of exposure to $\mathrm{N}_{2} \mathrm{O}$ (or $\mathrm{N}_{2}$ in the control group) the analgesic effect was measured by means of the tailflick testing over $120 \mathrm{~min}$. Measurements of tail-flick latency were repeated at $15,30,60,90$, and $120 \mathrm{~min}$ after the start of $75 \% \mathrm{~N}_{2} \mathrm{O}$ (or $\mathrm{N}_{2}$ ) exposure or morphine injection.

To assess the analgesic effect of $\mathrm{N}_{2} \mathrm{O}$, tail-flick latency (Analgesia meter, MK-330, Muromachi Kikai, Tokyo, Japan) was measured as previously described. ${ }^{16}$ Before $\mathrm{N}_{2} \mathrm{O}$ (or $\mathrm{N}_{2}$ ) exposure or morphine injection, three to five consecutive control measurements were performed; the median value of these measurements was taken as the baseline. The median value of three to five consecutive measurements at each time was calculated. The potency of the analgesic effect was evaluated by calculating the maximal possible effect (MPE) as follows: 
TFT - TFT'

$\% \mathrm{MPE}=$ X 100

\section{CO - TFT'}

where, TFT' is the baseline tail-flick time $(4-6 \mathrm{sec})$, TFT is the experimental tail-flick time, and $\mathrm{CO}$ is the cut-off time $(=10 \mathrm{sec})$.

Protocol for evaluation of NAergic neuronal transmission Rats were assigned to one of three groups:

i) Control $\left(\mathrm{N}_{2} 75 \%, \mathrm{n}=5\right)$

ii) $\mathrm{N}_{2} \mathrm{O}(75 \%, \mathrm{n}=6)$

iii) Morphine ( $5 \mathrm{mg} \cdot \mathrm{kg}^{-1}, i \mathrm{p}, \mathrm{n}=5$ )

The changes in NA content were measured in the LC bilaterally and the dorsal part of spinal cord. After 120 min of $\mathrm{N}_{2} \mathrm{O}$ (or $\mathrm{N}_{2}$ ) exposure or morphine injection, the rats were killed by decapitation. The brain and the spinal cord were quickly removed according to rat atlas and placed in an ice-cooled box at $4^{\circ} \mathrm{C}$ and were frozen with isopentane/freon $\left(-40^{\circ} \mathrm{C}\right)$. The tissue block was weighed and homogenized using an ultrasonic sonicator. After centrifugation at 10,000 rpm for $20 \mathrm{~min}$ at $-20^{\circ} \mathrm{C}, 50 \mu \mathrm{l}$ of the supernatant (approximately $0.3 \mathrm{ml}$ ) were used for determination of NA content using high performance liquid chromatography with an electrochemical detector (HPLC$\mathrm{ECD} ; 600 \mathrm{mv})$. The sensitivity of the assay for NA content was $5-10 \mathrm{ng} \cdot \mathrm{mg}^{-1}$. The assay was linear over the concentrations of $100 \mathrm{ng}$ to $2000 \mathrm{ng} \cdot \mathrm{mg}^{-1}$.

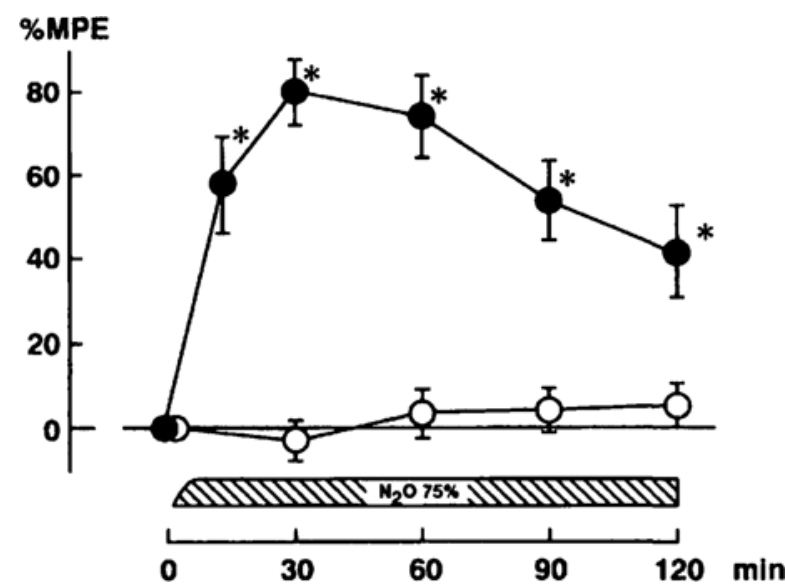

FIGURE 1 Time course of maximal possible effect (MPE) of nitrous oxide (75\%) in rats.(:nitrogen exposure $(n=8) ; \bullet$ : nitrous oxide exposure $(n=8)$, Values are mean $\pm S E M$,

${ }^{\star} P<0.05$ compared with control.

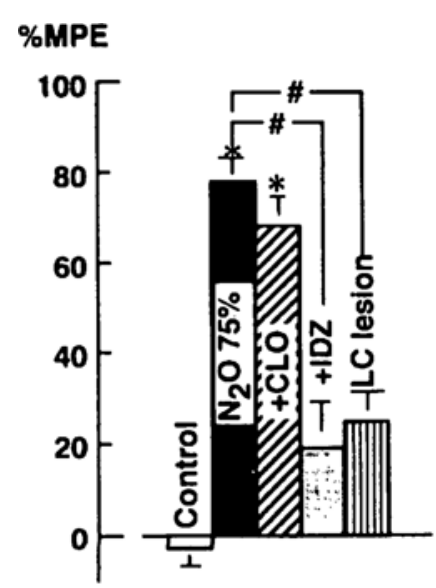

$30 \mathrm{~min}$

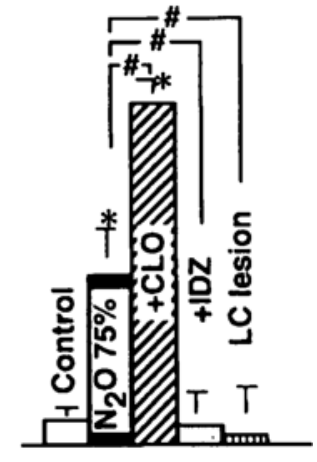

$120 \mathrm{~min}$
FIGURE 2 Modification of the analgesic effect of nitrous oxide with various treatments assessed after $30 \mathrm{~min}$ and $120 \mathrm{~min}$ exposure.

$P<0.05$ compared with control \# or with nitrous oxide alone*

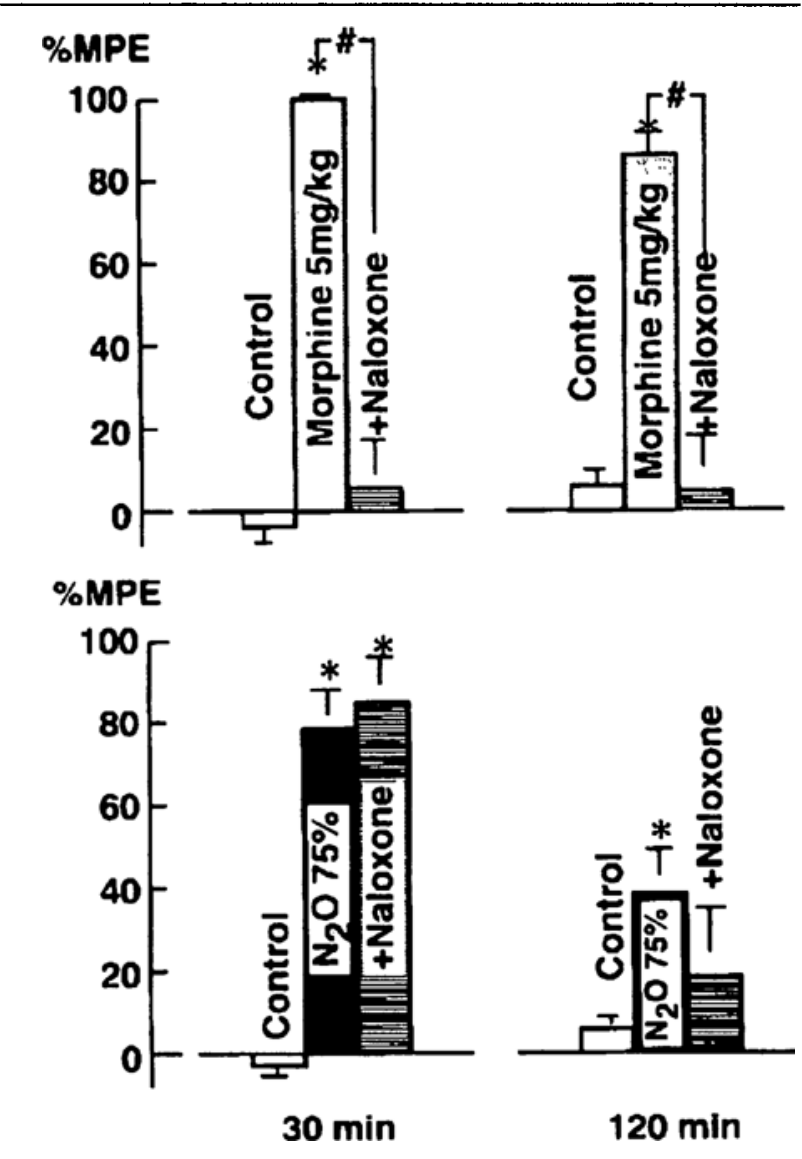

FIGURE 3 Modification of nitrous oxide or morphine analgesia by naloxone assessed after $30 \mathrm{~min}$ and $120 \mathrm{~min}$ exposurc to nitrous oxide or morphine administration.

$P<0.05$ compared with control* $^{*}$ or with nitrous oxide group \# 
TABLE Effect of $\mathrm{N}_{2} \mathrm{O}$ exposure on NA content in CNS (ng.mg $\mathrm{mg}^{-1}$ ).

\begin{tabular}{lll}
\hline Group & Spinal cord $(I-I I)$ & $L C$ \\
\hline $\begin{array}{l}\text { Control } \\
(\mathrm{n}=5)\end{array}$ & $549 \pm 57$ & $1430 \pm 144$ \\
$\begin{array}{l}\mathrm{N}_{2} \mathrm{O} \\
(\mathrm{n}=6)\end{array}$ & $442 \pm 68^{*}$ & $680 \pm 81^{*}$ \\
$\begin{array}{l}\text { Morphine } \\
(\mathrm{n}=5)\end{array}$ & $411 \pm 104$ & $985 \pm 128$ \\
\hline
\end{tabular}

Values indicate mean \pm SEM

* $(P<0.05)$ compared with Control group

\section{Statistical analysis}

Results are presented as means \pm SEM. For evaluation of both analgesic effect by \% MPE and the NA content among groups, significant differences were tested by one-way analysis of variance (ANOVA) followed by the least significance difference (LSD) method for multi-comparison of means. $P<0.05$ was considered to be significant.

\section{Results}

\section{Analgesic effect of $\mathrm{N}_{2} \mathrm{O}$ and its modification}

The time course of the analgesic effect as expressed by $\% \mathrm{MPE}$ in the rats exposed to $\mathrm{N}_{2} \mathrm{O}$ alone and to $\mathrm{N}_{2}$ is shown in Figure 1. The rats in the control group consistently demonstrated no change and stable \% MPE values throughout the 120 min observation period. In the $\mathrm{N}_{2} \mathrm{O}$ alone group, \% MPE increased, reaching a maximum of $78 \%$ at $30 \mathrm{~min}$, thereafter \% MPE declined to $38 \%$ at $120 \mathrm{~min}(P<0.05)$. Since the analgesic effect of $\mathrm{N}_{2} \mathrm{O}$ was attenuated with time, the modification with various pretreatment was assessed at $30 \mathrm{~min}$ and $120 \mathrm{~min}$. These two time points could be representative as interpretation over $120 \mathrm{~min}$. The intravenous injection of clonidine did not affect the analgesic effect of $\mathrm{N}_{2} \mathrm{O}$ at $30 \mathrm{~min}$ exposure (\% MPE, 70\%), but potentiated $\mathrm{N}_{2} \mathrm{O}$-induced analgesia at $120 \mathrm{~min}$ (\% MPE, $80 \% ; P<0.05)$. By contrast, intravenous pretreatment with IDZ and LC lesioning attenuated the analgesic effect of $\mathrm{N}_{2} \mathrm{O}$ (Figure 2).

After intravenous pretreatment with naloxone the \% MPE increase produced with morphine was blocked. However, the \% MPE increase with $\mathrm{N}_{2} \mathrm{O}$ was only partially blocked and this did not reach statistical difference (Figure 3).

\section{Noradrenergic neuronal transmission}

In the $\mathrm{N}_{2} \mathrm{O}$ group, NA content was greater in the LC than in the dorsal horn of its spinal cord. Nitrous oxide decreased NA content by $52 \%$ in the LC and by $20 \%$ in the dorsal part of spinal cord $(P<0.05)$. With morphine, NA content did not change, compared with control, in any region (Table).

\section{Discussion}

The principal findings of the present study are: i) the antinociceptive effect of $\mathrm{N}_{2} \mathrm{O}$ was inhibited by the $\alpha_{2}$ receptor antagonist idazoxane and by $\mathrm{LC}$ lesioning, ii) $\mathrm{N}_{2} \mathrm{O}$ decreased the NA content at spinal cord. This suggests that supra-spinal NAergic activation plays a pivotal role in the antinociceptive response to $\mathrm{N}_{2} \mathrm{O}$ in the spinal cord which confirmed the findings of a recent report. ${ }^{15}$

Mediation of $\mathrm{N}_{2} \mathrm{O}$ induced analgesia by the enkephalinergic system has been postulated previously but there remains some controversy. Guo et al. ${ }^{15}$ demonstrated that $\mathrm{N}_{2} \mathrm{O}$ analgesia may be mediated by activation of a descending inhibitory NAergic pathway that may, in turn, be activated by opioid receptors in the PAG region. They suggested that both supra-spinal opioid and spinal $\alpha_{2}$ adrenoceptors played a mediating role in the antinociceptive effect of $\mathrm{N}_{2} \mathrm{O}$ in rats. The present study provides additional evidence that NA neuronal activity, in particular the analgesic effect, was inhibited by both $\alpha_{2}$ receptor antagonist and LC lesioning, and activation of NAergic neuronal transmission that decreased NA content in the spinal cord which reflects increased release ${ }^{17}$ and leads to activation of $\alpha_{2}$ receptor localized at $\mathrm{C}$ fibre terminal and dorsal horn neurons. This means that descending NAergic neurons originating from the LC to substantia gelatinosa of spinal cord, the site of $\mathrm{C}$ fibre input, are involved in the mechanism of $\mathrm{N}_{2} \mathrm{O}$ analgesia. However, although naloxone was given systematically, it is difficult to determine whether its site of action of opioid activity concerned with $\mathrm{N}_{2} \mathrm{O}$ analgesia is supra-spinal or spinal level.

\section{$\mathrm{N}_{2} \mathrm{O}$ analgesia and its modification: involvement of NAergic neuronal activity in CNS}

The present study showed that $\mathrm{N}_{2} \mathrm{O}$ analgesia, evaluated by the tail-flick test, was enhanced by the systemic delivery of an $\alpha_{2}$ receptor agonist and was inhibited by $\alpha_{2}$ receptor antagonists or by LC lesioning. Thus, we suggest that $\mathrm{N}_{2} \mathrm{O}$ analgesia may be mediated by activating the central NAergic system.

Tail-flick testing is a reflection of the multi-synaptic spinal reflex via polymodal $C$ fibres with high-threshold nociceptive stimuli. Therefore, the present results indicate that the analgesic effect of $\mathrm{N}_{2} \mathrm{O}$ is mediated by modulation of primary afferent sensory transmission via C fibres as a presynaptic event, and/or postsynaptic event. Thus, inhibition of the primary afferent sensory transmission by $\mathrm{N}_{2} \mathrm{O}$ appears to be mediated by activation of the central NAergic system. 
Based on the present results i) LC lesioning attenuated the analgesic effect of $\mathrm{N}_{2} \mathrm{O}$ and, ii) $\mathrm{N}_{2} \mathrm{O}$ markedly decreased the NA content at the LC. According to Lisopraweki et al., ${ }^{17}$ accumulation or depletion of neurotransmitter in a specific region is due to decrease or increase, respectively, in release from the neuron terminal. Thus, the increased NA release from the LC neuron (activation of NA neuron at LC), suggests that at least part of the antinociceptive effect of $\mathrm{N}_{2} \mathrm{O}$ involves stimulation of the LC neuron leading to activation of the descending NA inhibitory pathway and increased release of NA at spinal level. Lesioning of the LC did not abolish the analgesic effect of $\mathrm{N}_{2} \mathrm{O}$, suggesting that $\mathrm{N}_{2} \mathrm{O}$ produced an analgesic effect, at least in part, by other mechanisms which might include supra-spinal enkephalinergic neurons. ${ }^{15}$

Recent concepts of analgesic mechanisms suggest that one of the pivotal regulatory systems is situated in the dorsal horn of the spinal cord. For example, morphine may inhibit substance $\mathrm{P}(\mathrm{sP})$ release from primary afferents nerve terminal in the dorsal horn, and it may also activate descending inhibitory neurons originating from the PAG and reticular nuclei ${ }^{7,8}$ via descending NAergic and serotoninergic pathways. The NAergic descending system originating from the LC modulates synaptic transmission of primary afferent $\mathrm{C}$ or $\mathrm{A} \delta$ fibres at pre and post synaptic neurons of the spinal cord via the activation of $\alpha_{2}$ receptor and by inhibiting release of $\mathrm{sP} .{ }^{18,19}$

Using an electrophysiological method, the analgesic effect of $\mathrm{N}_{2} \mathrm{O}$ results from inhibiting spontaneous firing in the dorsal horn of spinal cord in cats. ${ }^{1,20} \mathrm{~A}$ number of pharmacological studies subsequently indicated that $\mathrm{N}_{2} \mathrm{O}$ analgesia may be mediated by $\mu$-opioid receptors. Berkowitz et al. ${ }^{2}$ reported that, in mice, $\mathrm{N}_{2} \mathrm{O}$ has a potent antinociceptive effect to chemical and heat stimuli in a dose-dependent manner, and that this effect was antagonized by naloxone. In addition, Zuniga et al. ${ }^{5}$ showed that the analgesic effect of $\mathrm{N}_{2} \mathrm{O}$ was attenuated by PAG lesioning in rats. This effect was correlated with the inhaled $\mathrm{N}_{2} \mathrm{O}$ concentration and the $B$-endorphin content of hypothalamus or PAG. However, a large amount of naloxone was needed to antagonize $\mathrm{N}_{2} \mathrm{O}$ analgesia. ${ }^{2}$ In addition, a recent report indicated that $\mathrm{N}_{2} \mathrm{O}$ analgesia was more likely to be mediated by $\mathrm{\kappa}$-opioid receptors than by $\mu$-opioid receptors. ${ }^{2 l}$ We could not show any involvement of opioid neuronal activity on $\mathrm{N}_{2} \mathrm{O}$ analgesia using naloxone at a dose that antagonized morphine analgesia. Taken together, involvement of opiate receptors in mediating with $\mathrm{N}_{2} \mathrm{O}$ analgesia remains controversial.

In the present study, to correlate behavioural changes with synaptic events, we measured NA content in both the LC and superficial layer of the dorsal horn of the spinal cord. The decrease in NA content in LC and spinal cord support the concept that $\mathrm{N}_{2} \mathrm{O}$ produced an antinociceptive effect by activating both supra-spinal and spinal NAergic neurons.

NAergic nerve fibres are widely distributed throughout the central nervous system including the substantia gelatinosa of the dorsal horn, that originated from the LC. ${ }^{10}$ Microscopical observation has demonstrated that, in the dorsal horn of the spinal cord, $\alpha_{2}$ receptors are densely localized at pre and postsynaptic sites of $C$ and $A$ fibres. ${ }^{10}$ Furthermore, $\alpha_{2}$ receptor activation exerts potent inhibition on nociception through the mechanisms of i) increased $\mathrm{Gi} / \mathrm{K}^{+}$conductance-adenylate cyclase system resulting in hyperpolalization of WDR neurons ${ }^{20}$ and, ii) inhibition of presynaptic neurotransmitter release form $\mathrm{C}$ fibres coupled with Go / N-type $\mathrm{Ca}$ channels. ${ }^{22}$ NAergic neuronal fibres located in the spinal cord originate mostly from the LC. ${ }^{10}$ Electrical stimulation of the LC caused an antinociceptive effect to the dorsal horn neurons of the spinal cord. ${ }^{23}$ Therefore, the NAergic neuronal system originating from the LC is thought to be a principle component of the descending inhibitory pathway. In fact, in spinal transected rats, clonidine suppresses veratridine-evoked release of substance $\mathrm{P}$ from slices of rat spinal cord $\mathrm{d}^{22}$ and also clonidine-evoked prolongation of tail-flick latency. ${ }^{11}$ Thus, it appears that clonidine produces a potent anti-nociceptive effect by activation of $\alpha_{2}$ receptors in the dorsal horn of the spinal cord. In addition, Ishikawa ${ }^{24}$ has demonstrated that $\mathrm{N}_{2} \mathrm{O}$ exposure increased $\mathrm{sP}$ content at spinal cord, suggesting $\mathrm{N}_{2} \mathrm{O}$ decreases $\mathrm{sP}$ release from afferent nerve terminal of the small fibre and that is consistent with attenuation of $\mathrm{sP}$ release by activation of $\alpha_{2}$ receptors in the dorsal horn of the spinal cord. These earlier data together with the present results provide substantial support for the involvement of NAergic neuronal activity in $\mathrm{N}_{2} \mathrm{O}$ analgesia.

\section{Comparison with morphine analgesia}

In this study, we confirmed that morphine produced marked analgesia and that this analgesic effect was blocked by systemic delivery of naloxone. Also, the effect of NAergic synapse transmission by morphine was examined to compare it with the action of $\mathrm{N}_{2} \mathrm{O}$. Our results showed that with morphine, NA content did not alter. The potent antinociceptive effect of morphine is mediated by activation of supra-spinal neurons located in the PAG or paragigant cellular reticular nucleus. ${ }^{7,25}$ Therefore, morphine may produce analgesia by interacting not only by activation of spinal cord containing interneurons, but also with the descending inhibitory system, NAergic and/or sero- 
toninergic pathway via an activation of opioid receptors at the supraspinal level. In the present study, NA content with morphine was decreased although not statistically significant, suggesting that increases in NA release at the spinal level are related to activation of interneurons of spinal cord and/or LC activation. We cannot exclude the possibility that morphine produces activation of NAergic inhibitory system.

Based on these results, it appears that the mechanisms for $\mathrm{N}_{2} \mathrm{O}$ analgesia may be mediated by activation of the NAergic system at supra-spinal and spinal cord levels which appears to be different from that of opioid (morphine) analgesia. However, the present study needs confirmation that $\mathrm{N}_{2} \mathrm{O}$ analgesia is mediated by activation of opiate receptors localized at periaquaductal grey (PAG) and dorsal horn of spinal cord.

In summary, it is suggested that $\mathrm{N}_{2} \mathrm{O}$-induced analgesia is mediated by activation of both supra-spinal and spinal NAergic neurons, that this leads to presynaptic inhibition of primary afferent neurotransmitter release as well as hyperpolarization of dorsal horn neurons in the spinal cord.

\section{Acknowledgment}

This study was supported in part by Scientific Research Grant No. 04454388 from Japanese Ministry of Education to T.I.

\section{References}

1 Kitabata $L M$, Taub A, Sato I. Lamina-specific suppression of dorsal horn unit activity by nitrous oxide and by hyperventilation. J Pharmacol Exp Ther 1971; 176: 101-8.

2 Berkowitz BA, Finck AD, Ngai $S H$. Nitrous oxide analgesia: reversal by naloxone and development of tolerance. J Pharmacol Exp Ther 1977; 203: 539-47.

3 Zuniga JR, Knigge $K K$, Joseph SA. Central B-endorphin release and recovery after exposure to nitrous oxide in rats. J Oral Maxillofac Surg 1986; 44: 714-8.

4 Quock RM, Kouchich FJ, Tseng L-F. Influence of nitrous oxide upon regional brain levels of methionineenkephalin-like immunoreactivity in rats. Brain Res Bull 1986; 16: 321-3.

5 Zuniga J, Joseph S, Knigge $K$. Nitrous oxide analgesia: partial antagonism by naloxone and total reversal after periaqueductal gray lesions in the rat. Eur J Pharmacol 1987; 142: 51-60.

6 Levine JD, Gordon NC, Fields HL. Naloxone fails to antagonize nitrous oxide analgesia fro clinical pain. Pain 1982; 13: 165-70.

7 Yeung JC, Rudy TA. Multiplicative interaction between narcotic agonisms expressed at spinal and supraspinal sites of antinociceptive action as revealed by concurrent intrathecal and intracerebroventricular injections of morphine. J Pharmacol Exp Ther 1980; 215: 633-42.

8 Stoelting RK. Opiate receptors and endorphins: their role in anesthesiology. Anesth Analg 1980; 59: 874-80.

9 Glazer EJ, Ross $L L$. Localization of noradrenalinergic terminals in sympathetic preganglionic nuclei of the rat: demonstration by immunocytochemical localization of dopamine-ß-hydroxylase. Brain Res 1980; 185 : 39-49.

10 Unnerstall JR, Kopajtic TA, Kuhar MJ. Distribution of $\alpha_{2}$ agonist binding sites in the rat and human central nervous system: analysis of some functional, anatomic correlates of the pharmacologic effect of clonidine and related adrenergic agents. Brain Res Rev 1984; 319: 69-101.

11 Zemlan FP, Corrigan SA, Pfaff DW. Noradrenergic and serotonergic mediation of spinal analgesia mechanisms. Eur ) Pharmacol 1980; 61: 111-24.

12 Yamamoto $T$, Yaksh TL. Comparison of the antinociceptive effects of pre- and posttreatment with intrathecal morphine and MK801, an NMDA antagonist, on the formalin test in the rat. Anesthesiology 1992; 77:757-63.

13 Malmberg $A B$, raksh TL. Pharmacology of the spinal action of ketorolac, morphine, ST-91, U50488H, and L-PIA on the formalin test and an isobolographic analysis of the NSAID interaction. Anesthesiology 1993; 79: 270-81.

14 Taksh TL. Pharmacology of spinal adrenergic systems which modulate spinal nociceptive processing. Pharmacol Biochem Behav 1985; 22: 845-58.

15 Guo T-Z, Poree L, Golden W, Stein J, Fujinaga $M$, Maze $M$. Antinociceptive response to nitrous oxide is mediated by supraspinal opiate and spinal $\alpha_{2}$ adrenergic receptors in the rat. Anesthesiology 1996; 85: 846-52.

16 D'Amour FE, Smith $D L$. A method for determining loss of pain sensation. J Pharmacol Exp Ther 1941; 72: 74-9.

17 Lisoprawski A, Blanc G, Glowinski J. Activation by stress of the habenulo-interpeduncular substance $P$ neurons in the rat. Neurosci Lett 1981; 25: 47-51.

18 Reddy SVR, YakshTL. Spinal noradrenergic terminal system mediates antinociception. Brain Res 1980; 189: $391-401$.

19 raksh TL, Reddy SVR. Studies in the primate on the analgesic effects associated with intrathecal actions of opiate $\alpha$-adrenergic agonists and baclofen.

Anesthesiology 1981; 54: 451-67.

20 Murata K, Nakagawa I, Kumeta $\Upsilon$, Kitahata LM, Collins $J G$. Intrathecal clonidine suppresses noxiously evoked activity of spinal wide dynamic range neurons in the cat. Anesth Analg 1989; 69: 185-91.

21 Quock RM,Graczak LM. Influence of narcotic antagonist drugs upon nitrous oxide analgesia in mice. Brain Res 1988; 440: 35-41. 
22 Ono $H$, Mishima $A$, Ono S, Fukuda $H$, Vasko MR.

Inhibitory effects of clonidine and tizanidine on release of substance $P$ from slices of rat spinal cord and antagonism by $\alpha$-adrenergic receptor antagonists.

Neuropharmacology 1991; 30: 585-9.

23 Sullivan AF, Dashwood MR, Dickenson AH. $\alpha_{2}$-adrenoceptor modulation of nociception in rat spinal cord: location, effects and interactions with morphine. Eur J Pharmacol 1987; 138: 169-77.

24 Ishikawa $T$. Nitrous oxide decreases substance P receptor binding in the rat spinal cord. J Neurosurg Anaesth 1989; 1: 316-22.

25 Jones $S L$, Gebhart GF. Characterization of coeruleospinal inhibition of the nociceptive tail-flick reflex in the rat: mediation by spinal $\alpha_{2}$-adrenoceptors. Brain Res 1986; 364: 315-30. 